\title{
UNITED STATES DURING THE COLD WAR 1945-1990
}

\author{
Novita Mujiyati \\ Pascasarjana Pendidikan Sejarah Universitas Sebelas Maret \\ email: novitamujiyati2@gmail.com

\section{Kuswono} \\ Pendidikan Sejarah FKIP Universitas Muhammadiyah Metro \\ email: kuswono@ummetro.ac.id \\ Sunarjo \\ Pendidikan Sejarah FKIP Universitas Muhammadiyah Metro
}

\begin{abstract}
Abstrak
Amerika Serikat dan Uni Soviet merupakan negara di pihak sekutu yang keluar sebagai pemenang pada Perang Dunia II. Namun, setelah mencapai kemenangan di pihak sekutu situasi segera berubah, kawan telah menjadi lawan. Amerika Serikat dan Uni Soviet saling bersaing untuk memperluas pengaruh serta kekuasaan. Untuk dapat bersaing Amerika Serikat berusaha terus memperkuat diri baik itu pada bidang ekonomi maupun militer dengan mebentuk pakta pertahanan dan badan bantuan dalam bidang perekonomian. Pada Perang Dingin keduanya memang tidak berperang secara langsung pada salah satu negara dari Uni Soviet maupun Amerika Serikat. Namun jika dipahami, teradinya Perang Korea dan Perang Vietnam merupakan dampak dari ketegangan antara kedua negara tersebut dan merupakan peperangan secara langsung yang dilakukan oleh Amerika Serikat dan Uni Soviet. Perang Dingin berakhir dengan runtuhnya Uni Soviet dan Amerika Serikat muncul menjadi negara pemenang.

Kata kunci: Amerika Serikat, Perang Dingin
\end{abstract}

\section{Abstract}

United States and the Soviet Union is a country on the part of allies who emerged as the winner during World War II. However, after reaching the Allied victory in the situation soon changed, man has become an opponent. United States and the Soviet Union are competing to expand the influence and power. To compete the United States strive continuously strengthen itself both in the economic and military by establishing a defense pact and aid agencies in the field of economy. During the Cold War the two are not fighting directly in one of the countries of the former Soviet Union and the United States. However, if understood, teradinya the Korean War and the Vietnam War is a result of tensions between the two countries and is a direct warfare conducted by the United States and the Soviet Union. Cold War ended in conflict with the collapse of the Soviet Union and the United States emerged as the winner of the country.

Keywords: United States of America, the Cold War

\section{PENDAHULUAN}

Belakangan ini banyak

bermunculan kalangan masyarakat

terutama anak muda mengenakan

aksesoris berupa lambang PKI (Partai

Komunis Indonesia). Penulis mulai

tersadar ketika dikalangan akademisi pun telah banyak beredar buku-buku berhaluan sosialis komunis setidaknya sejak tahun 2014. Pro dan kontra mengenai hal ini terjadi di berbagai kalangan. Fenomena tersebut menarik dan menginspirasi penulis untuk mencoba membahas kembali mengenai 
pergulatan Perang Dingin yang terjadi antara Amerika Serikat dan Uni Soviet tidak lepas dari dampak Perang Dunia II 1945 sampai dengan tahun 1990-an. Sebagaimana yang kita ketahui bahwa Perang Dunia II yang dimenangkan oleh pihak Sekutu telah melahirkan persoalan baru. Hubungan Amerika Serika dan Uni Soviet yang semula adalah kawan kini telah berubah menjadi lawan dalam menyebarkan pengaruh ideologinya di Dunia yaitu Komunis dan Liberal. Amerika Serikat yang saat itu, masih lemah karena berbagai persoalan serta kekacauan di dalam negeri melakukan politik tertutup bagi negaranya. Namun, karena melihat perkembangan yang ada di Eropa dimana Uni Soviet terus melebarkan sayapnya, berusaha mempengaruhi negara-negara yang lemah dengan komunisnya, tentu hal ini menjadi ancaman bagi Amerika Serikat.

Dengan berbagai pertimbangan yang ada, pada akhirnya Amerika Serikat merasa terpanggil untuk mencegah perkembangan Komunis yang jelas berbeda dengan ideologi liberal yang dianut oleh Amerika Serikat. Uni Soviet merupakan ancaman terbesar bagi Amerika Serikat pasca Perang Dunia II, dimana pada awalnya Uni Soviet lebih kuat jika dibandingkan dengan Amerika Serikat. Untuk mencegah semakin berkembangnya komunis, Amerika Serikat melaksanakan beberapa kebijakan baik itu berupa pembentukan pakta pertahanan bersama antara Amerika Serikat dan Eropa Barat yang meliputi pelaksanaan Truman Doctrine, kebijakan Marshall Plan maupun organisasi-organisasi pertahanan bersama yaitu NATO.

Jika kita lihat sepintas antara Amerika Serikat dan Uni Soviet dalam Perang Dingin, terlihat bahwa keduanya hanya berperang dalam konflik ideologi, tidak pernah ada perang langsung antara keduanya, namun jika dipahami lebih jauh lagi ternyata konflik ideologi tersebut telah membawa dunia pada arena peperangan. Salah satu contohnya adalah perang Korea yang sebenarnya merupakan salah satu dampak dari Perang Dingin. Korea Utara mendapat dukungan dari Uni Soviet sementara Korea Utara dibantu oleh Amerika Serikat. Konflik berkepanjangan di Korea dan pertikaian di Vietnam adalah bentuk peperangan secara nyata yang dapat kita amati dari dampak Perang Dingin.

Berakhirnya Perang Dingin ditandai dengan Runtuhnya Uni Soviet dan lahirlah Amerika Serikat sebagai satu-satunya negara yang sangat berpengaruh di Dunia. Sekali lagi Amerika Serikat membuktikan bahwa pertahanannya mampu membawanya pada kemenangan sehingga sesuatu yang wajar jika Amerika Serikat saat ini menjadi negara yang sangat berwibawa dimata Dunia Internasional. Sampai saat 
inipun membahas mengenai hegemoni ideologi masih tetap menarik, bahkan tak dielakan lagi bahwa walaupun Uni Soviet telah hancur namun bagi Amerika Serikat dan kroninya ideologi komunis tetap dianggap sebagai ancaman yang sewaktu-waktu dapat muncul kembali.

\section{METODE PENELITIAN}

Metode yang digunakan dalam penelitian ini adalah metode sejarah sebagaimana menurut Helius Sjamsuddin (2007:15), “Metode Sejarah itu merupakan suatu prosedur atau metode yang digunakan untuk tahu bagaimana mengetahui". Maka untuk tahu bagaimana mengetahui, ada empat tahapan yang dilakukan dalam penelitian ini yaitu, heuristik atau mengumpulkan sember-sumber sejarah yang berkaitan dengan penelitian baik berupa buku, jurnal maupun sumber lainnya yang berkaitan dengan Perang Dingin dan sejarah Amerika Serikat. Penelusuran sumber dilakukan di perpustakaan pusat UNS dan perpustakaan Pusat UM Metro. Setelah diperoleh sumber-sumber sejarah maka data tersebut diverifikasi (kritik ekstern dan intern) sehingga didapat data yang terpercaya. Tahap selanjutnya adalah memberikan interpretasi terhadap datadata tersebut menjadi fakta-fakta dan historiografi dimana peneliti menyampaikan hasil yang diperoleh dari tiga tahap sebelumnya dalam bentuk karya tulis sejarah. Terdapat beragam penyebutan nama negara semisal Amerika yang dalam hal ini diartikan sama dengan Amerika Serikat.

\section{PEMBAHASAN}

Kebijakan Amerika Serikat Pasca Perang Dunia II

Pasca Perang Dunia II, telah berakibat buruk bagi Amerika Serikat meskipun Amerika Serikat berada pada pihak yang memenangkan perang tersebut. Akibat yang paling jelas terlihat adalah dalam bidang ekonomi, sebagaimana dijelaskan oleh Michalle Anugrah (2005:298) bahwa prioritas pertama Trauman segera setelah pasca perang adalah melakukan transisi keperekonomian masa damai. Mereka yang selesai bertugas ingin segera pulang, tapi begitu tiba di tanah airnya, mereka menghadapi persaingan dalam hal perumahan dan pekerjaan. The G.I Bill (RUU Ketentaraan) yang disetujui sebelum perang berakhir, meringankan beban veteran untuk kembali kekehidupan sipil dengan menyediakan keuntungan seperti misalnya jaminan pinjaman untuk membeli rumah dan bantuan keuangan untuk pelatihan industri dan pendidikan di Universitas. Yang lebih menghawatirkan adalah keresahan pekerja. Ketika produksi perang berhenti, banyak pekerja menganggur. 
Pasca Perang Dunia II, Amerika Serikat menutup diri dari dunia luar, mencoba memperbaiki kembali kondisi politik, ekonomi, serta sosial yang carut marut di dalam negeri. Berbagai kecaman serta tuntutan dari rakyat mengharuskan Pemimpin Amerika Serikat pada saat itu yaitu Presiden Truman bekerja keras untuk mengembalikan kepercayaan rakyat. Banyak dari para prajurit perang yang sebelumnya direkrut tidak jelas nasibnya dan jumlah prajurit yang ada memang harus dikurangi karena negara tidak membutuhkan lagi prajurit sebanyak pada saat Perang Dunia II, para korban perang yang masih hidup juga menuntut perhatian dari pemerintah Amerika Serikat.

Mengutip dari Tanto (2011: 74) menulis bahwa sementara Amerika sangat sibuk dengan urusan dalam negerinya, perkembangan komunis di Amerika telah mencapai perkembangan yang sangat luar biasa. Situasi demikian merupakan tanda bahaya, karena pada dasarnya komunisme merupakan musuh bebuyutan paham demokrasi yang menjadi landasan hidup bangsanya dan sekutu Eropa Barat. Kecemasan yang begitu besar mendorong Amerika Serikat untuk melepaskan diri dari politik isolasi yang hidup kembali sesudah perang.

Dari penjelasan tersebut dapat kita pahami bahwa dengan melihat kenyataan bahwa pengaruh komunis,
Uni Soviet semakin meluas tentu saja meresahkan Amerika Serikat. Kondisi negaranya yang belum sembuh seutuhnya dari luka Perang Dingin terpaksa harus dipaksa untuk mebuka balutan luka tersebut, agar dapat merasakan udara panas yang mengancam bagi ideologi Amerika Serikat. Dengan dibukanya politik isolasi dari Amerika Serikat maka terbukalah Perang Dingin bagi Amerika Serikat dan Uni Soviet.

\section{Perang Dingin Antara Amerika Serikat dan Uni Soviet}

Perang Dingin menurut Michael Kort (1998:4) merupakan suatu kondisi dunia yang hidup dalam bayangan perang nuklir, suatu kondisi dimana dunia diwarnai ketegangan “damai tetapi tidak damai" karena pelatuk konflik perang nuklir masing-masing dunia siap meledak. Perang Dingin antara Amerika Serikat dan Uni Soviet diawali oleh kecurigaan dari masingmasing pihak baik itu Uni Soviet maupun Amerika Serikat. Kecurigaan tersebut terus berkembang hingga muncul semacam persaingan untuk saling berunjuk kekuatan dalam hal ini adalah kekuatan militer. Ketegangan terus terjadi antara keduanya yang semakin memperkeruh keadaan pada masa itu.

Menurut Robert McNamara (1989:26-27), konflik Perang Dingin ini terjadi karena AS telah melakukan salah persepsi (misperception) tentang 
ideologi komunis yang menekankan "class struggle". Pertama, doktrin "Socialism in One Country", yang oleh pihak barat diartikan bahwa Uni Soviet menghendaki sebagai satu-satunya negara sosialis yang menguasai dunia. Doktrin ini tampak pada sikap keras Stalin, Lenin, dan Kruschev. Kecurigaan itu makin besar dengan meluasnya pengaruh komunisme pada sejumlah negara dunia ketiga yang kemudian banyak beralih menjadi negara komunis. Tercatat banyak negara komunis baru misalnya komunisme Cina yang menang mengalahkan kaum Nasionalis (1949), Uni Soviet secara sepihak mendirikan administrasi ekonomi di Jerman Timur (1947). Setelah itu Polandia, Bulgaria dan Rumania menjadi pemerintahan komunis (1947) yang kemudian disusul Chekoslovakia dan Hungaria. Melihat kenyataan ini AS merasa khawatir bahwa negara-negara lain akan terpengaruh juga oleh ideologi komunis, sebab komunis menjanjikan perubahan secara revolusioner dan anti kapitalis.

Konflik ideologi inilah yang membawa Amerika Serikat dan Uni Soviet ada pada posisi persaingan yang tidak mau kalah satu sama lain. Amerika merasa tidak ingin tersaingi dan dengan berbagai upaya berusaha menekan perkembangan komunis, untuk itu berupaya memberikan bantuan terhadap negara-negara di Eropa Barat dan melakukan perjanjian dengan beberapa negara selain itu juga membentuk organisasi pertahanan bersama.

Pertahanan Amerika Serikat dalam Bidang Ekonomi dan Militer

Dalam usaha untuk membendung kekuatan komunis Amerika Serikat melaksanakan beberapa langkah menuju pertanana yang kuat dengan negaranegara di dunia ke tiga. Diantaranya adalah dalam bidang ekonomi dengan pelaksanaan Truman Doctrine dan Marshall Plan serta lembaga-lembaga perekonomian dunia diantaranya adalah IMF, Bank Dunia, GATT yang sekarang dikenal dengan WTO. Sementara dalam bidang militer dimana Amerikan Serikat dibentuklah aliansi NATO (North Atlantic Treaty Organization) pada tahun 1954. Sementara pada kawasan lain ia menjalin hubungan dengan Cina Nasionalis (1954), membentuk ANZUS (1951), SEATO (1954), serta mengadakan perjanjian dengan Iran, Turki dan Pakistan. Kebijakan Amerika Serikat dalam bidang ekonomi maupun militer penting kiranya untuk dibahas secara terperinci.

\section{Pelaksanaan Truman Doctrine}

Truman Doctrine adalah bantuan ekonomi dan militer Amerika Serikat yang diberikan untuk Yunani dan Turki. Dimana pada saat itu Uni Soviet yang telah berhasil melebarkan sayap kekuasaannya di Eropa Timur, dikhawatirkan akan menarik Yunani dan Turki dalam genggaman tangan besinya. 
Seperti halnya negara lain, keadaan pasca Perang Dunia II, merupakan keadaan sulit yang dialami oleh Yunani dan Turki. Kedua negara mengalami kekacauan serta telah menjadi target perluasan paham komunis.

Letak wilayah Yunani yang dekat dengan wilayah sekutu Uni Soviet mengakibatkan negara tersebut otomatis terkepung dan tidak lagi memiliki kekuasaan secara luas di dalam negaranya sendiri. sebagaimana mengutip dari Tanto (2011:96-97) bahwa Uni Soviet yang telah berhasil menarik Eropa Timur ke dalam kungkungan Tirai besi berusaha memperluas wilayah pengaruhnya dengan cara memaksa Yunani dan Turki ke dalam pengawasannya. Dimata Amerika dan Inggris, tindakan Uni Soviet itu merupakan tanda bahaya. Mereka membayangkan posisi kedua negara tersebut tidak leluasa. Hal ini disebabkan karena mereka telah dikepung oleh musuh-musuh ideologi sekutu Uni Soviet yakni Albania, Yugoslavia, dan Bulgaria.

Negara yang mengalami kekacauan selalu dimanfaatkan oleh Uni Soviet untuk memperluas kekuasaannya, demikian halnya yang terjadi dengan Turki yang pada dasarnya tidak jauh berbeda dengan keadaan Yunani. Turki adalah target untuk dikuasai oleh Uni Soviet. Baik turki maupun Yunani sangat membutuhkan bantuan karena keadaan ekonomi, politik serta sosial yang sangan memperihatinkan. Inggris yang pada awalnya memberikan bantuan, ternyata sudah tidak sanggup lagi untuk memberikan bantuan dan menghadapi komunis. Sementara PBB tidak berdaya dalam menyelesaikan masalah Turki dan Yunani. Kebijakan yang dikeluarkan PBB selalu mendapat veto dari Uni Soviet karena kebijakan yang dikeluarkan jelas akan mengganggu kepentingan Uni Soviet. Dengan kondisi yang demikian rumit pada akhirnya presiden Amerika Serikat pada saat itu yaitu Truman, mengambil langkah untuk memberi bantuan serta kebijakan terhadap Yunani dan Turki yang kita kenal dengan Truman Doctrine.

\section{Kebijakan Marshall Plan}

Perang Dingin yang mengakibatkan pembagian Eropa memudarkan tujuan mengenai kesatuan Eropa. Banyak dari penganjur Kesatuan Eropa yang lebih besar, termasuk Winston Churcill dari Inggris, kehilangan kekuasaan politik di negara-negara mereka sendiri. Selain faktor-faktor ini, sebagai persoalan praktis, banyak orang Eropa yang menaruh perhatian bukan terhadap debat filosofis tentang politik dan ekonomi tetapi dengan permasalahan dasar seperti persediaan makanan, bahan bakar, tempat berlindung, dan rekonstruksi fisik. Sulit untuk berpikir dalam kaitan dengan unifikasi Eropa Raya ketika susah untuk mencari 
makanan. Untuk membantu orang Eropa kembali membumi dan mendorong terbentuknya pemerintah yang kuat dan bersahabat, Menteri Luar Negeri AS George C. Marshall merekomendasikan agar Amerika Serikat menyediakan sejumlah besar bantuan keuangan kepada negara-negara Eropa untuk membantu rekonstruksi mereka. Dengan demikian lahirlah Rencana Marshall (Marshall Plan). Marshall Plan adalah bantuan yang muncul dalam Konferensi Paris tahun 1947 ini diberikan kepada negara-negara Eropa Barat.

Pembentukan NATO (North Atlantic Treaty Organization)

Sebagaimana yang telah disampaikan di atas bahwa berakhirnya Perang Dunia II tidak berarti perang telah selesai namun inilah masa baru dalam sejarah dunia. Kekalahan pihak fasis mendorong demokrasi semakin berkembang. Namun demikian demokrasi terpecah dalam beberapa paham lagi, diantaranya adalah demokrasi liberal yang diusung oleh Amerika Serikat dan Ideologi Komunis yang diusung Oleh Uni Soviet (Mariam Budiarjo, 2008:105). Perbedaan ideologi yang mereka usung membawa persaingan yang ketat terutama dalam bidang militer saat itu. Amerika Serikat yang merasa bahwa keadaan yang demikian merupakan suatu ancama akhirnya memutuskan untuk melakukan integrasi dengan negara-negara Eropa
Barat dan melakukan sebuah perundingan yang disebut dengan TheNorth Atlantic Treaty Organization di Washington DC pada tanggal 4 April 1949. Hasil dari perundingan tersebut adalah terbentuklah sebuah pakta pertahanan yaitu NATO yang beranggotakan 12 negara masing-masing terdiri dari negara Eropa Barat dan Amerika Utara.

Negara-negara yang tergabung dalam NATO sepakat bahwa pembentukan pakta pertahanan tersebut memiliki tujuan untuk memelihara perdamaian, dan keamanan bersama untuk melawan berbagai ancama apapun yang membahayakan negara-negara tersebut serta hubungan baik diantara anggota dan negara lain di luar anggota. Sebagaimana yang di sampaikan oleh Temple (1964:128) bahwa Keberadaan NATO dimaksutkan untuk membangun rasa percaya diri anggotanya, sehingga dapat memperkuat kekuatan barat secara moral dan material untuk melawan kemungkinan bahaya yang diakibatkan ekspansi komunis Uni Soviet. Hal ini senada dengan tulisan Tanto (2011:179) bahwa sesuai dengan piagam organisasi NATO dapat disimpulkan bahwa tujuan NATO adalah: (1) Menjaga keamanan di kawasan Atlantik Utara Menghidupkan konsultasi di antara negara-negara anggota tentang keutuhan daerah, kebebasan politik 
atau keamanan apabila terancam sewaktu-waktu. (3) Siap menggunakan kekuatan militer untuk menghadapi setiap serangan yang mengancam setiap anggota.

Dengan terbentuknya NATO dengan otomatis wilayah yang berada di bawah naungan Amerika Serikat lebih memiliki keberanian dalam menghadapi kemungkinan pengaruh komunis Uni Soviet yang semakin meluas. Berdasarkan jurnal yang ditulis oleh Yulita menerangkan bahwa berdirinya NATO membuat langkah Amerika Serikat untuk menanggulangi komunisme dan menandingi Uni Soviet dapat diwujudkan dengan mudah.

Uni Soviet sebagai negara yang tidak telibat dalam pakta pertahanan tersebut, tentu saja memberikan kecaman. Uni Soviet melalui mentri Luar Negerinya menyampaikan rasa keberatan dan tidak menyetujui dengan terbentuknya pakta pertahanan tersebut. Namun hal tersebut tidak menjadi rintangan bagi anggota NATO, untuk melaksanankan kesepakatan yang telah dibuat. Melihat keadaan yang demikian maka tindakan yang diambil Uni Soviet adalah memebentuk pakta pertahanan untuk mengimbangi kekuatan Amerika Serikat.

AZUS (Australia, New Zeland dan United States)

AZUS adalah suatu kerjasama yang dilakukan oleh Australia dan
Amerika Serikat dalam bidang militer. Dengan kerjasama militer ini Amerika Serikat memiliki kepentingan untuk mencegah perluasa komunis di Asia Pasifik sehingga mengembangkan Aliansi dengan Australia. Selain itu tantangan geopolitik yang dihadapi oleh Australia dalah dengan munculnya kekuatan Cina, khususnya dengan terus meningkatnya kekuatan pertahanan dan klaim Cina terhadap laut Cina Selatan yang mencakup beberapa pulau di gugusan kepulauan Spratly sebagai tindakantindakan Cina untuk memperluas kekuatan dan pengaruh di Asia Pasifik. Oleh sebab itulah, juga penting bagi Australia untuk merangkul Amerika Serikat. Yuli Trisnawati (2014:65) menyatakan bahwa sebagai negara adidaya Amerika Serikat berusaha menjadi yang terdepan di dalam segala bidang, perkembangan dan peningkatan power Cina membuat Amerika Serikat khawatir akan pengurangi pengaruh serta eksistensinya di kawasan Asia Pasifik.

Dari hal tersebut jelas bahwa kerjasama Amerika Serikat dalam berbagai bidang dengan negara-negara regional selalu tidak lepas dari sebuah kepentingan yang kaitannya dengan Perang Dingin. AZUS adalah sebuah pertahanan militer yang penting bagi keseimbangan kekuatan untuk melindungi kawasan Asia pasifik. 
SEATO (South East Asea Treaty Organization)

SEATO atau pakta pertahanan yang berada di Asia Tenggara merupakan sebuah langkah yang dilakukan oleh Amerika Serikat untuk merangkul wilayah di Asia Tenggara, seperti halnya NATO pembentukannya tidak lepas dari pengaruh Perang Dingin. Mengutip dari sebuah jurnal dari Murtamadji bahwa dalam arena politik Internasional organisasi yang dibentuk berasumsi bahwa dengan pembentukan kerjasama pertahanan dan keamanan regional dan pembentukan organisasi politik, ekonomi, regional, dan lain-lain, serta negara-negara yang merasa senasip sepenanggungan dalam satu wilayah regional maupun banyak kemiripan tradisi dan budaya bersamaan kepentingan, bisa diharapkan organisasi kerjasama pada tingkat regional akan punya prospek yang lebih cerah untuk menangani masalah perang dan damai secara politik.

SEATO merupakan organisasi pertama di Asia Tenggara yang terbentuk pada tanggal 8 September 1954 di Manila. Adapun anggota dari SEATO adalah Amerika Serikat, Inggris, Perancis, Australia, Selandia Baru, Pakistan, Philiphina dan Mungthai. Dari negara-negara tersebut dapat dilihat bahwa hanya ada dua negara di wilayah Asia Tenggara yang ikut dalam organisasi Pakta Pertahanan SEATO ini sehingga secara otomatis kridibilitasnya sangat lemah. Namun yang perlu digaris bawahi disini adalah bahwa pembentukan SEATO ini tidak lepas dari sebuah kepentingan terutama politis seperti yang telah dijelaskan di atas. SEATO dibentuk dengan tujuan utamanya adalah membendung pengaruh dari Komunisme oleh Uni Soviet.

Beberapa Konflik dampak Perang Dingin

Beberapa peperangan serta ketegangan yang terjadi di dunia ketiga pada pasca Perang Dunia II hingga runtuhnya Uni Soviet tidak bisa dilepaskan dari pertikaian yang terjadi antara kedua kubu tersebut. Amerika Serikat serta Uni Soviet memang tidak pernah berperang secara langsung pada salah satu dari kedua wilayah yang bersangkutan. Namun peperangan antara Amerika Serikat dan Uni Soviet terjadi di Dunia ke tiga.

Sebagaimana yang ditulis oleh William L. Bradley dan Mochtar Lubis (1991:95) menyatakan bahwa pertikaian yang menyita umat manusia dala "masa pasca perang" tersebut merupakan bencana besar yang tidak sehebat dua Perang Dunia sebelumnya, akan tetapi menuntut biaya yang luar biasa dari para peserta maupun penonton dan semua gembira untuk melihat akhir dari masalah itu. Siapa pemenang dan siapa yang kalah dalam perjuangan yang 
menakutkan ini antara negara-negara adikuasa itu? Pemenang yang paling jelas adalah dua negara yang dikalahkan dalam Perang Dunia II, Jepang dan Jerman maupun bangsa-bangsa di Eropa Tengah yang memperoleh kemerdekaan mereka. Siapa yang kalah? Yang paling pasti ialah Uni Soviet, akan tetapi juga korban manusia dari konflik negara Adikuasa: korban perang di Korea, Indocina, Afganistan, dan Nikaragua maupun mereka yang gagal dalam perjuangan mereka untuk kemerdekaan di kedua sisi Tirai Besi.

Perang Dingin yang berlangsung dalam kurun waktu yang lama ini telah membawa dunia ketiga masuk dalam arena peperangan dan perpecahan yang dibelakangnya didorong sebuah kepentingan baik itu dari Uni Soviet maupun Amerika Serikat. Diantara peperangan dan ketegangan yang terjadi disekitar Perang Dingin yang akan dibahas dalam makalah ini adalah Perang Korea dan Perang Vietnam. Setidaknya dua contoh peperangan tersebut dapat menjadi sebuah gambaran bagaimana sebuah kepentingan mengendarai negara-negara ketiga.

\section{Perang Korea}

Perang antara Korea Utara dan Korea Selatan dimulai pada tanggal 25 Juni 1950 dan berakhir pada 27 Juli 1953. Perang Saudara ini terjadi akibat tidak adanya kesepakatan antar Uni
Soviet dan Amerika Serikat mengenai masa depan semenajung Korea. Baik Uni Soviet maupun Amerika Serikat memainkan peranannya masing-masing sebagai pihak yang menang dalam Perang Dunia II, yang sebelumnya Semenanjung Korea merupakan wilayah yang diduduki oleh fasis Jepang pada awal tahun 1900-an.

Mengutip dari William L. Bradley dan Mochtar Lubis (1991-106) mengenai pembagian Korea yang dalam hal ini adalah persetujuan para Menteri Luar Negeri pada pertemuan di Moskow, 30 Desember 1945 yaitu: 1. Mengingat pembentukan kembali Korea sebagai negara merdeka, diciptakannya keadaan untuk pembangunan negara atas dasardasar demokratik dan dilenyapkannya secepat munkin atas dominasi Jepang yang berlarut-larut di Korea yang membawa malapetaka, akan dibentuk pemerintahan sementara Korea yang demokratis, yang akan mengambil semua langkah yang diperlukan untuk mengembangkan industri, pengangkutan dan pertanian Korea serta kebudayaan nasional rakyat Korea. 2. Supaya dapat membantu pembentukan pemerintahan sementara Korea dan mengingat perincian pendahuluan dari tindakantindakan yang tepat, akan dibentuk komisi bersama yang terdiri dari wakilwakil komando Amerika Serikat di Korea bagian selatan dan Komando Uni Soviet di Korea bagian utara. Dalam 
menyiapkan usul-usul mereka, Komisi akan berkonsultasi dengan pihak-pihak demokratik dan organisasi sosial di Korea. Rekomendasi yang disusun oleh komisi itu akan diserahkan untuk pertimbangan pemerintah Uni Republik Sosialis Soviet, Cina, Inggris, dan Amerika Serikat sebelum keputusan akhir oleh kedua pemerintah yang diwakili pada komisi bersama. 3. Akan menjadi tugas komisi bersama, dengan partisipasi pemerintah sementara Korea yang demokratis dan organisasi demokratik di Korea untuk menyusun pula tindakan-tindakan untuk membantu dan menolong (perwakilan) kemajuan politik, ekonomi dan ekonomi rakyat Korea, pengembangan pemerintah sendiri yang demokratis dan pembentukan kemerdekaan nasional Korea. Usul-usul komisi bersama tersebut, sesudah konsultasi dengan pemerintahan sementara Korea, akan diserahkan untuk pertimbangan bersama oleh Pemerintah Amerika Serikat, Uni Republik Sosialis Soviet, Inggris, dan Cina untuk penyususnan persetujuan tentang perwalian empat-negara untuk korea selama masa lima tahun. 4. Untuk pertimbangan masalah mendesak yang mempengaruhi Korea bagian Selatan maupun Korea bagian utara dan untuk perincian tindakan penetapan koordinasi permanen dalam soal-soal administratif ekonomis antara Komando Amerika Serikat di Korea bagian Selatan dan
Komando Soviet di Korea bagian utara, dalam waktu dua minggu akan diadakan konprensi antara para wakil komando Amerika Serikat serta komando Soviet di Korea.

Jika kita lihat bagaiman isi dari pembagian wilayah Korea yang telah di setujui para mentri luar negeri pada pertemuan di moskow 30 desember 1945, tidak berlebihan kiranya jika saya berpandangan perang saudara di Korea itu wajar terjadi. Hal yang mendasarinya adalah jelas pembagian tersebut akan memisahkan korea Utara dan Selatan karena Ideologi yang menaungi sangat berbeda yaitu Komunisme dan Liberalisme. Pembagian kedua wilayah tersebut pada perjalanan waktu terbukti di tunggangi oleh kepentingan baik Uni Soviet maupun Amerika Serikat pada masa Perang Dingin. Keduanya terus bersaing untuk menunjukkan siapa yang paling kuat hingga tidak bisa membendung terjadinya perang Saudara.

Pertempuran antara Korea Utara dan Korea Selatan ini pertama kali diawali dengan, penyerangan Korea Utara yang di dukung oleh Uni Soviet terhadap Korea Selatan di bawah naungan Amerika Serikat. Dalam penyerangan tersebut sangat terlihat keunggulan dari Korea Utara, hal ini di sebabkan karena Korea Utara di dukung sepenuhnya oleh Uni Soviet terutama dalam bidang persenjataan. Sedangkan 
Korea Selatan pada saat itu belum memiliki senjata yang memadai untuk melawan Korea Utara, karena dalam kenyataannnya saat itu Amerika Serikat belum sepenuhnya mendukung Korea Selatan.

Dalam melakukan serangan balasan, pihak Amerika Serikat yang saat itu di pimpin oleh Presiden Harry $S$ Truman terlihat lambat untuk memberikan dukungan terhadap Korea Selatan di pertempuran Semenanjung Korea. Hal ini di sebabkan karena Amerika Serikat belum sepenuhnya memberikan perhatiannnya terhadap wilayah tersebut. Bahkan pada saat teradi peperangan pada saat itu, yang mengambil inisiatif untuk melakukan serangan balasan adalah Jendral Douglas MacArthur seorang komandan pertahanan Amerika Serikat yang berkedudukan di Tokyo. Namun tetap saja serangan balasan yang dilakukan oleh Korea Selatan tidak dapat menandingi kekuatan dari Korea Utara yang didukung sepenuhnya dari Uni Soviet. Keputusan yang lambat untuk memberikan bantuan terhadap Korea Selatan ini akhirnya memicu jendral Douglas MacArthur mengambil keputusan gencetan senjata pada tanggal 27 juli 1953 dan mengakui keunggulan dari Korea Utara. Tanggal tersebut merupakan kenangan bagi Korea Utara dimana dapat mengalahkan Amerika Serikat.

\section{Perang Vietnam}

Perang Vietnam yang merupakan perang dalam jangka waktu yang panjang kira-kira terjadi dalam dalam kurun waktu 20 tahun lamanya. Perang Vietnam ini terjadi pada tahun 19541975. Perang ini melibatkan Amerika Serikat dan Uni Soviet dan menjadi pukulan bagi Amerika Serikat, karena dalam perang ini Amerika Serikat menenmui kekalahan.

Seperti halnya dalam pembahasan perang sebelumnya, Vietnam pada masa peperangan terbagi menjadi dua kubu yaitu Vietnam Utara dan Vietnam Selatan. Pemisahan ini terjadi karena kedua bagian negara tersebut menganut ideologi yang berbeda. Vietnam Utara menganut paham komunis yang didukung oleh Rusia atau Uni Soviet dan Cina. Sedangkan Vietnam Selatan menganut ideologi liberal karena Vietnam selatan diduduki oleh Amerika Serikat dan negara-negara bagian barat, terutama Perancis.

Vietnam pada awalnya adalah negara jajahan Perancis yang telah merdeka pada tahun 1945. Namun karena pada masa kemerdekaan perdebatan mengenai kekuasaan tidak dapat dihindari ataupun diredam maka sehingga menjadi kesempatan masuknya Perancis ke wilayah Vietnam Selatan. Dengan masuknya Perancis ke wilayah Vietnam Selatan ini maka Vietnam Utara 
merasa berhak untuk memperjuangkan kemerdekaan kembali. Amerika Serikat yang sebelumnya tidak terlibat dalam pertikaian ini, memutuskan untuk berperan karena apabila Vietnam Utama berhasil memenangkan konflik maka negara tersebut akan menjadi komunis. Disinilah letak benang merah, mengapa perang yang terjadi di Vietnam termasuk dalam peperangan yang merupakan pengaruh dari Perang Dingin antara Amerika Serikat dan Uni Soviet.

Perang Vietnam ini berakhir dengan kemenangan Vietnam bagian Utara pada tanggal 30 April 1975 yang ditandai dengan pemerintah Vietnam di Saigon menyerah tanpa syarat kepada pasukan Vietnam Utara. Stasiun BBC mengungkapkan bahwa Presiden Doung Van Minh yang baru menjabat selama tiga hari, memerintahkan pasukannya untuk meletakkan senjata dan menyerukan agar pasukan Vietnam Utara dan Vietnam Selatan menghentikan permusuhan. Pengumuman menyerah itu diikuti dengan kedatangan pasukan Vietnam Utara. Kekalahan Vietnam Selatan ini merupakan kekalahan Amerika Serikat dalam memperjuangkan Ideologinya di wilayah Vietnam.

\section{Berakhirnya Perang Dingin dan}

\section{Munculnya Dominasi Amerika Serikat}

Kira-kira pada tahun 1970

berbagai kemunduran terlihat di Uni Soviet, terutama dalam bidang ekonomi.
Sebagaimana kita ketahui bahwa faktor ekonomi pada saat itu digunakan oleh Uni Soviet untuk memenuhi kekuatan militer yang harus terus bersaing dengan Amerika Serikat. Sebagaimana dikutip dari Wahjudi (2012:216) bahwa adapun masalah yang muncul di Uni Soviet antara lain ketidakpuasan kelas menengah dan kelompok elit pemerintah komunis sendiri, tekanan kelompok etnis non-Rusia, korupsi yang timbul di kalangan partai dalam pemerintahan, dana anggaran belanja yang defisit karena biaya pendudukan pasukan Uni Soviet di beberapa negara Eropa Timur, serta ketertinggalan teknoligi serta industri sehingga kapasitas produksi makanan untuk mencukupi kebutuhan rakyatnya menurun. Hal ini senada dengan apa yang disampaikan oleh Mikhail Gorbachev dalam buku Mikhail Gorbachev Prestorika pemikiran baru untuk negara kami dan dunia yang diterjemahkan oleh Boesoni Sondakh (1992:5) bahwa dalam menganalisis situasinya, pertama-tama kami menemukan bertumbuhnya berlangsungnya pertumbuhan ekonomi yang lambat. Dalam lima belas tahun terakhir tingkat pertumbuhan pendapatan nasional telah merosot lebih dari setengahnya, dan menjelang awal tahun '80-an turun mencapai tingkat yang nyaris menyamai stagnasi ekonomi. Sebuah negara yang pernah cepat sekali 
berendeng mendekati negara-negara maju di dunia mulai kehilangan posisi satu persat. Lagi pula, kesenjangan dalam efisiensi produksi teknologi maju dan penggunaan teknik canggih mulai melebar, dan bukan untuk keuntungan kami Hal inilah yang kemudian menandai keruntuhan dari Uni Soviet.

Runtuhnya Uni Soviet menjadi tanda bahwa Perang Dingin yang dimenangkan oleh Amerika Serikat. Dengan kemenangan yang dicapai oleh Amerika Serikat ini maka tentu banyak perubahan yang terjadi di negara tersebut. Sebagaimana dalah Buku Garis Besar Sejarah Amerika Serikat (2005:362) dijelaskan bahwa bagi kebanyakan orang Amerika, era 1990'an era perdamaian, kemakmuran dan perubahan teknologi yang deras. Beberapa mengaitkan dengan revolusi Reagan dan akhir dari Perang Dingin.

Sementara dalam dunia Internasional tidak bisa dipungkiri bahwa Amerika Serikat adalah negara adidaya yang telah keluar sebagai pemenang dalam Perang Dunia II dan Perang Dingin. Semenjak berakhirnya Perang Dingin kemajuan Amerika Begitu pesat baik dalam bidang ekonomi, politik, serta militer. Bahkan sejar 1990an Amerika Serikat berperan sebagai polisi dunia. Sebagaimana dalam salah satu jurnal yang ditulis oleh Sadam Hussein (2013) menjelaskan bahwa Amerika Serikat pada Perang Dunia II keluar sebagai juara, pasca Perang Dunia II cengkraman Amerika Serikat makin kuat dan sangat berpengaruh dalam skala Internasional, terlebih ketika akhir 80'an ketika Amerika Serikat kembali sebagai negara pemenang dalam Perang Dingin (Could War) yang melibatkan Amerika Serikat dan Uni Soviet sebagai dua aktor yang berseteru dalam perang tersebut. Melihat kedikdayaan Amerika Serikat pada saat itu pantaslah jika Amerika Serikat dikatakan sebagai negara hegemoni atau negara yang dapat mendisiplinkan negara lain sesuai dengan kepentingan dan keinginannya.

Jika kita pahami dengan apa yang terjadi pada masa sekarang ini, selepas berakhirnya Perang Dingin memang masa damai dapat dirasakan, ketakutan akan terjadinya perang besar secara langsung antara Amerika Serikat dan Uni Soviet dengan menggunakan kekuatan Nuklir memang tidak lagi ada, namun disini terlihat jelas dominasi Amerika Serikat terutama dalam bidang Politik dan Militer dalam kehidupan dunia. Kepentingan Amerika serikat selalu menjadi faktor penting yang mempengaruhi kehidupan dunia, dan hal ini terjadi karena tidak ada lagi penyeimbang dari Amerika Serikat. Meskipun pada bidang ekonomi Amerika Serikat tidak dapat meremehkan kemajuan Jepang dan Cina namun kedua 
negara tersebut tetap tidak dapat duduk sebanding dengan Amerika Serikat.

Kesimpulan

Selepas berakhirnya Perang Dunia II, harapan untuk dapat hidup damai ternyata masih belum tercapai. Kemenangan Sekutu telah membawa api persaingan yang semakin membara. Amerika Serikat yang awalnya melakukan politik tertutup untuk fokus membenahi negaranya yang porakporanda akibat Perang Dunia II pada perkembangannya mengambil langkah yang berani, yaitu membuka diri dan berusaha menekan pengaruh komunis yang semakin meluas.

Usaha Amerika Serikat terus ditingkatkan dengan membentuk pertahanan baik dibidang ekonomi maupun militer. Pembentukan pakta pertahanan tersebut tidak saja terbatas di wilayah Eropa Barat melainkan meluas kewilayah Asia. Persaingan yang begitu panas terus terjadi hingga pada akhirnya api peperangan menyala di beberapa negara, contohnya adalah di Vietnam dan Korea. Baik Amerika Serikat maupun Uni Soviet memang tidak pernah secara langsung berperang di wilayah negaranya, namun Perang Dingin justru berkobar di negara lain dimana negara tersebut di bawah pengaruh dari Amerika Serikat dan Uni Soviet.

Perang Dingin berakhir dengan runtuhnya Uni Soviet dan lahirnya
Amerika Serikat sebagai negara adidaya yang saat ini memiliki dominasi dan pengaruh yang kuat dalam kehidupan Internasional.

Saran

Sejarah adalah sebuah pembelajaran yang akan menjawab semua pertanyaan mengenai masa kini. Perang Dingin tetap menjadi suatu peristiwa yang harus kita pahami, dengan demikian kita mengetahui bagaimana sebuah dominasi yang terjadi saat ini. Tidak ada yang aneh dengan Amerika Serikat yang saat ini seakan menjadi kiblat negara-negara di dunia. Semuanya dapat dijelaskan secara logis jika kita memahami sejarah. Amerika Serikat yang dijuluki sebagai polisi dunia saat ini terbentuk oleh perjuangannya dimasa yang lalu.

Seperti kata Bung Karno "Jas Merah" jangan sekali-kali melupakan sejarah, fungsinya adalah untuk kita lebih bijaksana serta memahami segala sesuatu dalam berbagai hal. Kita akan tahu bagaimana sebuah kepentingan akan menjadikan kawan menjadi lawan, membenarkan prilaku yang salah, bahkan dapat merubah seorang manusia menjadi seekor manusia agar segala kepentingannya dapat terpenuhi. Dengan memahami sejarah kita tidak akan mengulangi kesalahan yang sama, karena Tupai pun tak pernah terjatuh pada lubang yang sama. 


\section{DAFTAR PUSTAKA}

Biro Program Informasi Internasional Departemen Luar Negeri Amerika Serikat (Penerjemah Michelle Anugrah). 2005. Garis Besar Sejarah Amerika Serikat. (Buku Online tanpa penerbit)

Helius Sjamsuddin. 2007. Metodologi Sejarah. Yogyakarta: Ombak

Joseph S. Nye, Jr. 1992. Memimpin Dunia Sifat Kekuasaan Amerika yang Berubah. Jakarta: Yayasan Obor Indonesia.

Mandalangi, J.Pareira. 1986. Segi-segi Hukum Organisasi Internasional. Bandung: Bina Cipta.

Michael Kort, 1998. TheColumbia Guide to the Cold War. New York: Columbia University Press.

Miriam Budiardjo. 2008. Dasar-dasar Ilmu Politi. Jakarta: Gramedia Pustaka Utama

Murtamadjid. 2009. Kegagalan Perang Dingin antara Dua Negara Adijaya: Faktor Penyebab dan Implikasi. Humanika: Vol 9 No 1 Halaman 8192

Robert S McNamara. 1989. Out of the Cold: New Thinking for American Foreign Policy in the $21^{\text {th }}$ Century. London: Bloomsbury.

Saddam Husein. 2013. Eksistensi Amerika Serikat sebagai Kekuatan Global. Global and Policy Vol 1 No. 1 halaman: 90

Suryokusumo, Sumaryo. 1987. Organisasi Internasional. Jakarta: Universitas Indonersia

Tample Wanamaker. 1964. America Foreign Policy Today. New York: Bantam Books

Tanto Sukardi. 2011. Perang Dingin Episode Sejarah Barat dalam Perspektif Konflik Ideologi. Yogyakarta: Pustaka Pelajar.

Wahyudi Djaja. 2012. Sejarah Eropa: Dari Eropa Kuni Hingga Eropa Modern. Yogyakarta: Ombak

William L. Bradley dan Mochtar Lubis. 1991. Dokumen-dokumen Pilihan Tentang Politik Luar Negeri Amerika Serikat dan Asia. Jakarta: Yayasan Obor Indonesia.
Yuli Trisnawati. 2014. Penempatan Pasukan Militer Amerika Serikat di Australia. E-Journal Hubungan Internasional. Volum 2 No 1. Halaman 59-70

Yulita Dewi Purwitasari. 2013. NATO: Kajian Implementasi Containment Policy Bidang Militer di Eropa (1949-1991). SOCl: Jurnal Ilmuilmu Sosial. Vol 10 no 2 halaman 156. 